\title{
Сорт вики посевной (яровой) Обская 16
}

\author{
А.В. Гончарова凶
}

Аннотация: Дана характеристика нового сорта вики посевной (яровой) Vica sativa L. Обская 16. Сорт включен в «Госреестр селекционных достижений РФ...» с 2019 г. по 10-му и 11-му регионам РФ.

Ключевые слова: вика посевная (яровая); новый сорт.

Благодарности: Сорт Обская 16 создан в рамках государственного задания 0324-2019-039-С1.

Для цитирования: Гончарова А.В. Сорт вики посевной (яровой) Обская 16. Письма в Вавиловский журнал генетики и селекции. 2020;6(1):1517. DOI 10.18699/Letters2020-6-03

\section{Spring common vetch sowing cultivar Obskaya 16}

\section{A.V. Goncharova $\bowtie$}

Abstract: The characteristics of cultivar of spring common vetch (Vica sativa L.) Obskaya 16 are given. The cultivar has been included in the "State Register of Breeding Achievements of the Russian Federation" from 2019 for the $10^{\text {th }}$ and $11^{\text {th }}$ regions of the Russian Federation. Key words: spring vetch; new commercial cultivar.

Acknowledgements: The cultivar Obskaya 16 was produced as part of the state assignment 0324-2019-039-C1.

For citation: Goncharova A.V. Spring common vetch sowing cultivar Obskaya 16. Pisma v Vavilovskii Zhurnal Genetiki $\mathrm{i}$ Selektsii = Letters to Vavilov Journal of Genetics and Breeding. 2020;6(1):15-17. DOI 10.18699/Letters2020-6-03 (in Russian)

\section{Описание сорта}

Сорт вики посевной (яровой) Vicia sativa L. Обская 16 создан отбором из гибридной популяции стародавнего красноярского сорта Камалинская 611 (разновидность tуріса) на сорт селекции СибНИИРС Новосибирскую (разновидность immaculata). Разновидность typica.

Стебель в период цветения имеет зеленую окраску с фиолетовым отливом. Высота растений в среднем 85-127 см, число междоузлий до первого соцветия 10-12, общее число междоузлий 19-25 (рисунок). Число бобов на растении: среднее - 14, максимальное - 46; среднее число семян в бобе 7-8 (см. рисунок, a).

Семена округлые. Окраска семян: черная бархатная $82 \%$, коричневая - 8 \%. Поверхность гладкая, блеск слабый. Масса 1000 семян 63-65 г.

За годы испытания (2015-2018) на госсортоучастках Новосибирской области урожай сухого вещества 63 ц/га, у стандарта - 58 ц/га, прибавка 9.3 ц/га. На участках Красноярского края, на Назаровском госсортоучастке урожайность сухого вещества у сорта Обская 16 составила 80.2 ц/га, у стандарта сорта Даринка - 71.0 ц/га; превышение 9,2 ц/га. Средний урожай семян у сорта Обская 16 - 30.4 ц/га, у стандарта сорта Даринка - 16.7 ц/га; прибавка составила 13.7 ц/га. Высота растений вики Обская 16-118 см, масса 100 семян 54.7-63.1 г.

Яровая вика является холодостойкой, но очень влаголюбивой культурой (Тюрин и др., 2013). Она хорошо произрастает на суглинистых серых лесных почвах и черноземах а также на нейтральных и слабокислых почвах (рH 6.0-6.5) (Леокене, 1964). Яровая вика Обская 16 дает высокие урожаи биомассы и семян в годы с достаточным увлажнением. Данный показатель является критическим при селекции для многих регионов мира (Georgieva et al., 2015; Дебелый, 2017).

Сорт вики посевной (яровой) Обская 16 районирован по продуктивности в 10-м и 11-м регионах (Государственный реестр..., 2019). Сорт удачно сочетает скороспелость с высокой кормовой и семенной продуктивностью (Гончарова, 2018). Требование к теплу зависит от времени вегетации. При возделывании яровой вики на кормовые цели требует- 


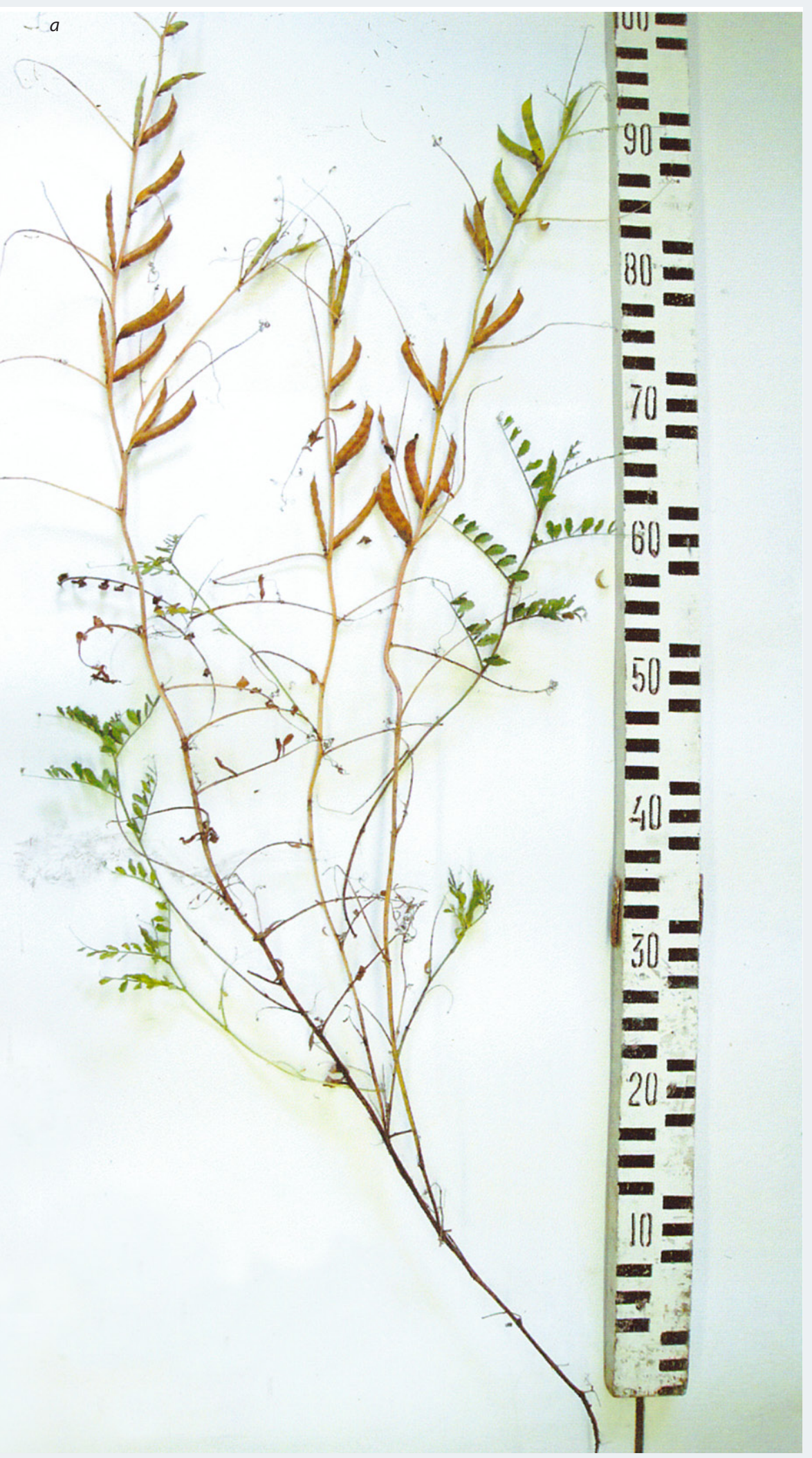




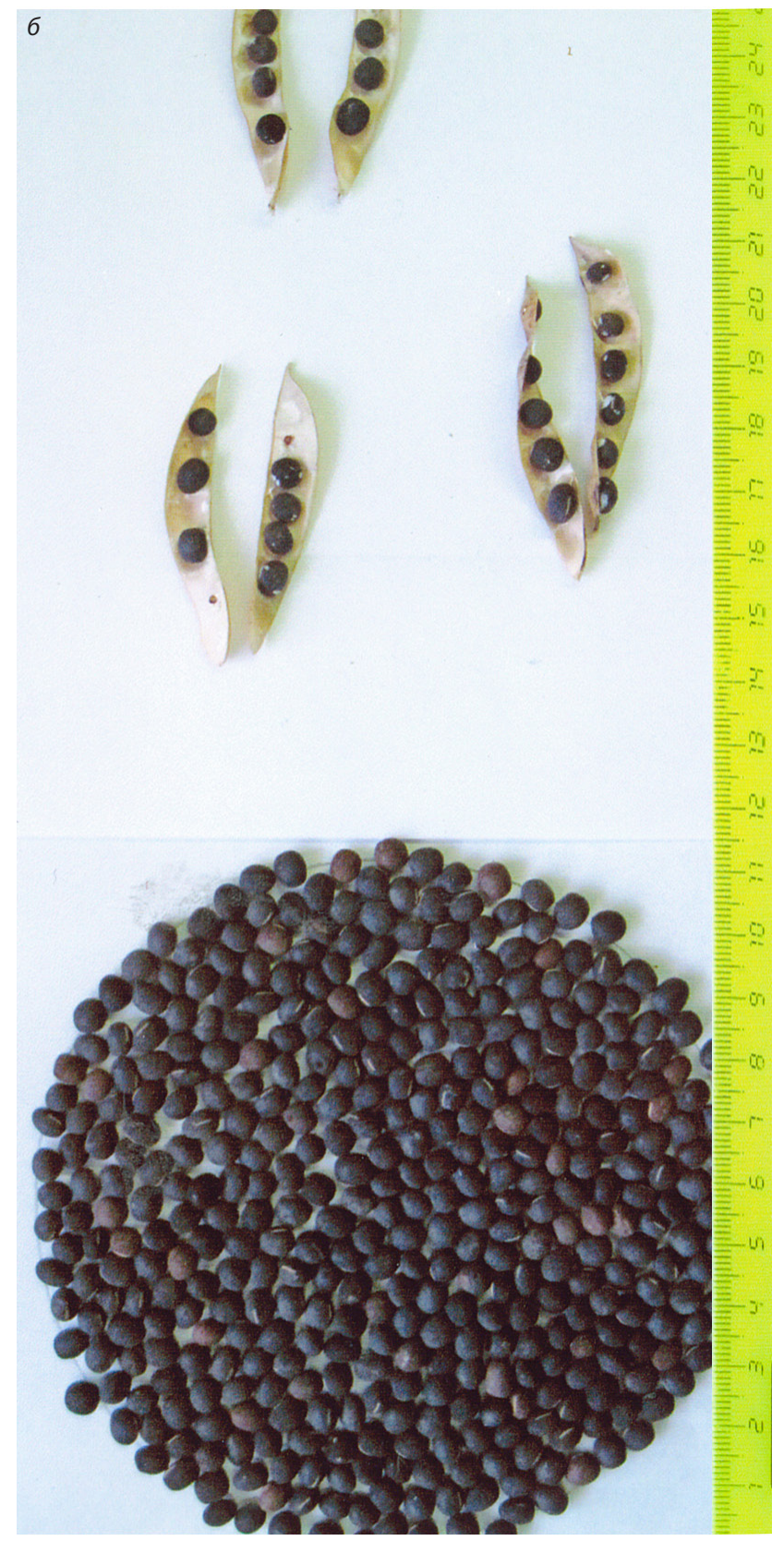

ся около $900^{\circ} \mathrm{C}$ суммарных положительных температур, при возделывании на семена около $1900^{\circ} \mathrm{C}$. Стебель до начала цветения растет медленно, цветение обычно наступает на 40-50-й день после появления всходов. При благоприятных условиях цветение может продолжаться 20-30 дней. Цветок раскрывается после 12 часов дня, на ночь закрывается. Продолжительность цветения одного цветка 30 часов. Образование бобов начинается в нижней части растения и постепенно идет вверх.

Учреждение-оригинатор: Сибирский научно-исследовательский институт растениеводства и селекции - филиал ИЦиГ СО РАН.

Авторы сорта:П.Л. Гончаров, А.В. Гончарова, Т.В. Ряттель, Е.Э. Андрусович.

\section{Список литературы / References}

Гончарова А.В. Новый сорт вики посевной Обская 16. Сибирский вестник сельскохозяйственной науки. 2018;48(6):37-42. DOI: 10.26898/0370-8799-2018-6-5.

[Goncharova A.V. A new cultivar of vetch Obskaya 16. Siberian Herald Agricultural Science. 2018;48(6):37-42. DOI: 10.26898/0370-87992018-6-5. (in Russian)]

Государственный реестр селекционных достижений, допущенных к использованию. Сорта растений (официальное издание). М.: ФГБНУ «Росинформагротех», 2019;1.

[The state register of selection achievements allowed for use. Plant varieties (official publication). Moscow: FSINI Rosinformagrotekh, 2019;1. (in Russian)]

Дебелый Г.А., Гончаров А.В., Меднов А.В., Вольпе А.А. Новые сорта яровой вики Московского НИИСХ «Немчиновка». Зернобобовые и крупяные культуры. 2017;2(22):84-87.

[Debely A.A., Goncharov A.V., Mednov A.V., Volpe A.A. New varieties of spring wiki of the Moscow NIISH «Nemchinovka». Legumes Cereals. 2017;2(22):84-87. (in Russian)]

Леокене Л.В. Яровая и озимая вика. Л.: Колос, 1964.

[Leoken L.V. Spring and winter vetch. Leningrad: Kolos, 1964. (in Russian)]

Тюрин Ю.С., Золотарёв В.Н., Косолапов В.М. Основные направления селекции и новые сорта вики яровой. Кормопроизводство. 2013;2:26-27.

[Tyurin Yu.S., Zolotarev V.N., Kosolapov V.M. The main breeding trends and new varieties of spring wiki. Feed Production. 2013;2: 26-27. (in Russian)]

Georgieva N., Nikolova I., Kosev V. Stability analysis for seed yield in vetch cultivars. Emirates Journal Food Agriculture. 2015;27(12):903910. DOI: 10.9755/ejfa.2015-04-172.

Конфликт интересов. Автор заявляет об отсутствии конфликта интересов.

Поступила в редакцию 23.01.2020. После рецензирования 17.02.2020. Принята к публикации 17.02.2020. 